EDINBURGH LEVENTIS STUDIES 3 
Previously published

Edinburgh Leventis Studies 1

Word and Image in Ancient Greece

Edited by N. Keith Rutter and Brian A. Sparkes

Edinburgh Leventis Studies 2

Envy, Spite and Jealousy: The Rivalrous Emotions in Ancient Greece

Edited by David Konstan and N. Keith Rutter 


\title{
ANCIENT GREECE: FROM THE MYCENAEAN PALACES TO THE AGE OF HOMER
}

\author{
Edited by \\ Sigrid Deger-Jalkotzy and Irene S. Lemos
}


(C) editorial matter and organisation,

Sigrid Deger-Jalkotzy and Irene S. Lemos, 2006

(C) the chapters their authors, 2006

Edinburgh University Press Ltd 22 George Square, Edinburgh

Typeset in 11 on 13 pt Times NR MT

by Servis Filmsetting Limited, Manchester, and printed and bound in Great Britain by Antony Rowe Ltd, Chippenham, Wilts

A CIP record for this book is available from the British Library

ISBN-10 0748618899 (hardback)

ISBN-13978 0748618897 (hardback)

The right of the contributors to be identified as author of this work

has been asserted in accordance with the Copyright, Designs and Patents Act 1988. 